\title{
ДЕЯКІ АСПЕКТИ РОЗВ'ЯЗАННЯ КОНФЛІКТІВ НА ПРИКЛАДІ КАФЕДРИ НЕВРОЛОГІЇ ОДЕСЬКОГО НАЦІОНАЛЬНОГО МЕДИЧНОГО УНІВЕРСИТЕТУ, ЯК ОДИН ІЗ НАПРЯМКІВ КУЛЬТУРИ СПІЛКУВАННЯ ТА ПІДВИЩЕННЯ ЯКОСТІ НАВЧАЛЬНОГО ПРОЦЕСУ
}

В. В. Добровольський

Одеський національний медичний університет

\author{
SOME ASPECTS OF CONFLICT SOLUTION ON EXAMPLE OF \\ NEUROLOGY DEPARTMENT OF ODESA NATIONAL MEDICAL \\ UNIVERSITY AS ONE OF THE AREAS CULTURE OF COMMUNICATION \\ AND ICREASE QUALITY OF EDUCATIONAL PROCESS
}

\author{
V. V. Dobrovolskyi
}

\section{Odesa National Medical University}

\begin{abstract}
У статті представлені деякі аспекти розв'язання конфліктів, як один із напрямків культури спілкування в колективі та підвищення якості навчального процесу на кафедрі неврології Одеського національного медичного університету. Ми намагаємося розв'язати конфлікт так, щоб виграли обидві сторони. Про це ми знаємо і до цього прагнемо. До того ж під час вирішення конфліктів можливо краще пізнати лідерів кафедри, 3 якими довелося спілкуватися в складній ситуації, оволодіти технікою попередження конфліктів та їх розв'язування. Тоді творчий потенціал, енергія, активність, комунікативні установки, якщо їх генератором і акумулятором є конфлікт, піднімуть культуру спілкування на вищий рівень, сприятимуть вирішенню проблем кафедри і університету в період кардинальних реформ у медицині взагалі, так і реформи медичної освіти відповідно.
\end{abstract}

The article presents some aspects of solution of conflicts as one of the areas of cultural communication in the team and increase of the quality of the educational process at the Neurology Department of Odesa National Medical University. We are trying to solve the conflict so as to benefit both parties. This we know, and we are going to this aim. In addition, during the conflict resolution may get to know the leaders of the department, which had to communicate in a difficult situation, to master the technique of preventing conflicts and solving them. Then, creativity potential, energy, activity, communication installations if the conflict is their generator and accumulator, may raise the culture of communication to a higher level, contribute to solving the problems of the department and the University during the cardinal reforms in medicine in general and reforms of medical education respectively.

Вступ. Наукою і життям доведено, що суспільство та особистість розвиваються згідно з законами діалектики: нове приходить через заперечення старого, а це значить і через конфлікти.

Після революції гідності в українському суспільстві йде процес реформування всіх сфер діяльності, які проходять у боротьбі нового зі старим. Те ж саме відбувається в усіх ланках життєдіяльності людей. Одеський національний медичний університет (ОНМедУ), як частина суспільства, наполегливо проводить у життя реформи, які підвищують

(c) В. В. Добровольський якість підготовки студентів, наближуючи їх до світових стандартів [1].

На цьому шляху стоїть і кафедра неврології ОНМедУ. Кардинальні реформи відбуваються не без конфліктів. Ми виходимо з того, що конфлікт це своєрідна страховка від застою, відсутність конфліктів несе в собі небезпеку затримки розвитку.

Конфлікт - це зіткнення протилежно спрямованих цілей, інтересів, позицій, думок, оцінок тощо. Знання психології конфліктів допомагає керівництву кафедри і університету визнати свою поведінку в таких ситуаціях, вирішити проблеми в колективі. 
В повсякденному житті, іноді говорячи про конфлікти, асоціюють його з агресією, сварками та ворожістю. Внаслідок цього стверджується думка, що конфлікт - небажане явище і його, по можливості, необхідно уникнути, а якщо ж він все ж виникне, то одразу вирішувати.

Ми вважаємо, що конфлікти не тільки можливі, але часом, в групах високого рівня розвитку інтелекту, культури і професіоналізму, якою є склад кафедри, бажані. Конфлікти допомагають виявити різні погляди, одержати додаткову інформацію керівництву, генерувати більшу кількість альтернатив для прийняття рішення, вийти на новий рівень якості підготовки студентів.

Конфлікти можуть бути функціональними. Тоді це сприятиме підвищенню ефективності діяльності роботи колективу кафедри, проведення консультацій та використання досвіду суміжних кафедр, що ми отримуємо на нарадах, які проводить керівництво факультету та університету, використовуємо рекомендації професійних психологів.

Таким чином, ми попереджуємо розвиток конфлікту, а у випадку виникнення його користуємося заходами, про які наголошуємо нижче.

Основна частина. Кафедра неврології ОНМедУ будує свою роботу по виявленню та розв'язуванню конфліктів за нижчеподаною схемою.

По-перше, за цільовою спрямованістю виділяються конфлікти конструктивні, стабілізуючі та неконструктивні. Конструктивний конфлікт позитивно впливає на структуру та результативність процесів i $є$ джерелом самовдосконалення й саморозвитку особистості. Конфлікт у групі може виконувати інтегруючу функцію, згуртувати членів колективу.

Конструктивний міжособистісний конфлікт буває тоді, коли опоненти не виходять за рамки ділових аргументів та відносин. При такому конфлікті керівництвом приймаються рішення, прийнятні для всіх. Це сприяє розвитку співробітництва, появі нових альтернатив та критеріїв їх оцінки.

Неконструктивний конфлікт виникає тоді, коли один із опонентів намагається психологічно тиснути на партнера, дискредитувати та принижувати його в очах членів кафедри, це звичайно викликає протидію. Вирішення проблеми стає неможливим. Акцент вирішення проблеми змінюється на здобуття перемоги будь-якою ціною [2].

Керівник - досвідчена та розумна людина, завжди може своєчасно помітити, що в особистому житті підлеглого намічається конфлікт. Це накладає відбиток на виконання обов'язків. Тут слід активно та оперативно допомогти колезі вийти з конфлікту. Керівник не може вносити у відносини між підлеглими дріб' язковість та злопам'ятність, не дозволяє собі особисті випади та помсту, не показує своєї антипатії, не виказує грубість, різкість, невитриманісь. Такий керівник зможе вирішувати конфлікти.

По-друге, важливу роль у вирішенні конфлікту має своєчасне визнання його суті. Для того щоб цього досягнути, важливо процес розділити на декілька етапів.

На першому етапі необхідно визначити основну проблему, яка привела до конфлікту [3].

Кожен член колективу має відповісти на ряд питань:

1. Які мої дії та дії партнера привели до виникнення конфлікту?

2. Які мої дії, на думку опонента, лежать в основі конфлікту?

3. Чи відповідає поведінка кожного з нас тій ситуації, що склалася?

4. Як можна найбільш лаконічно та повно визначити нашу спільну проблему?

5. В яких питаннях ми розходимося?

Аналізуючи відповіді, слід визначити причину конфлікту. Це важливо зробити для того, щоб вирішити конфлікт, а також, щоб не повторити його в майбутньому. Наступним кроком слід знайти можливі шляхи до розв'язання конфлікту. Потім обговорити проблему з іншою стороною, та прийняти спільне рішення про вихід з конфлікту, а надалі реалізувати намічений шлях його розв'язування.

По-третє, які ж основні правила попередження конфліктів?

Практично кожний конфлікт - чи то в діловій сфері, чи в особистій - має свою емоційну основу. Він нерідко торкається почуття гідності людини, викликає у неї потребу у самозахисті. Саме з цього треба виходити, щоб попередити конфлікт.

На кафедрі апробовані основні правила, застосовувати які ми пропонуємо для вирішення конфлікту:

а) необхідно визнавати одне одного як рівного партнера по спілкуванню;

б) слід слухати партнера не перебиваючи;

в) важливо демонструвати розуміння ролі іншого;

г) необхідно вияснити, як протилежна сторона сприймає конфліктну ситуацію і що при цьому відчуває;

д) важливо чітко формулювати предмет можливого зіткнення;

е) бажано встановити спочатку, що об'єднує, а потім - що роз'єднує;

є) слід спільно шукати рішення. 
Якщо ж конфлікт все-таки виникає, то слід не гаяти часу, а приступити до його розв'язування.

По-четверте, крім міжособлення стилів, що використовуються з метою вирішення конфліктів, на кафедрі застосовуються ще й так звані структурні методи:

1) своєчасне роз'яснення вимог щодо результатів та дій окремої особи колективу (це можливо зробити або на нараді, або в індивідуальному порядку);

2) у тому випадку, коли два або більше підлеглих мають розбіжності з якогось питання, конфлікту можливо запобігти, якщо рішення візьме на себе керівник кафедри за допомогою ланцюга вказівок;

3) загальноорганізаційні комплексні цілі (для ефективного досягнення таких цілей необхідно об’єднати зусилля або деяких членів кафедри, в тому числі тих, що конфліктують. Головна ідея спрямування зусиль всіх на досягнення однієї мети);

4) “система винагород” (використовується для того, щоб уникнути дисфункціональних наслідків, впливати на поведінку підлеглих, робити ії більш конструктивною).

Перш ніж звернутися до тих чи інших методів i стилей, варто спочатку приглушити емоції. Цей метод називається раціонально-інтуїтивним. Серед емоцій основними джерелами конфліктів є роздратування та недовіра. Треба припинити роздратування та перевірити обгрунтованість своїх сумнівів і тільки тоді приступити до розв’ язання конфлікту.

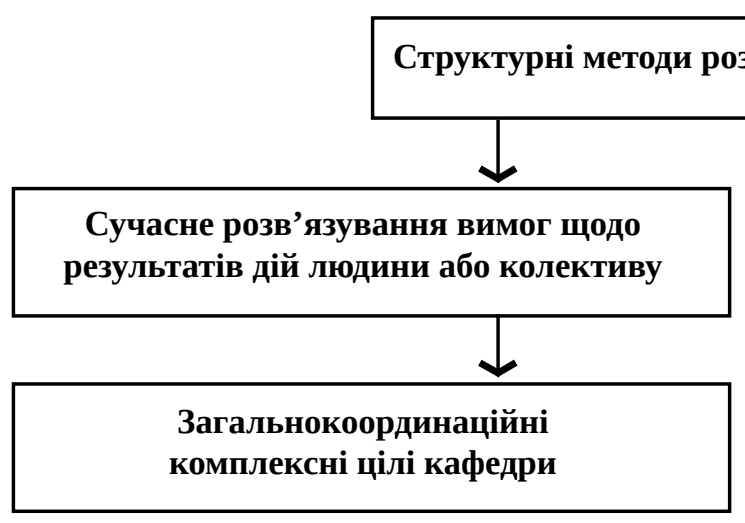

По-п'яте, самостійне розв'язування конфліктів. Знайти шлях до розв’язання конфлікту і реалізувати його можливо самостійно, якщо мислено подивитися на конфлікт наче збоку і проаналізувати його, оцінивши власну поведінку та поведінку іншої сторони. Основна умова конструктивного розв'язання конфліктів - вдосконаленість та ефективність спілкування сторін.

Позитивний результат при розв’ язанні конфліктів дає раціонально-інтуїтивний метод. Він передбачає:

а) використання розуму та інтуїції;

б) заглушення негативних емоцій, в першу чергу - роздратування.

Як краще позбавитися роздратування? Для цього треба наказати собі зупинитися, заспокоїтися та запропонувати це зробити й іншій стороні.

$€$ ряд складних конфліктних ситуацій, які важко розв'язувати самостійно. У цьому випадку необхідно звернутися за допомогою до третьої, нейтральної особи - посередника, яким у нашому випадку є керівництво кафедри та університету, які користуються найбільшим авторитетом. Перевага посередника у тому, що він не бере участі в конфліктній ситуації і не має негативних емоцій. При знайомстві з проблемою та сторонами посеред-

\section{'язування конфліктів}
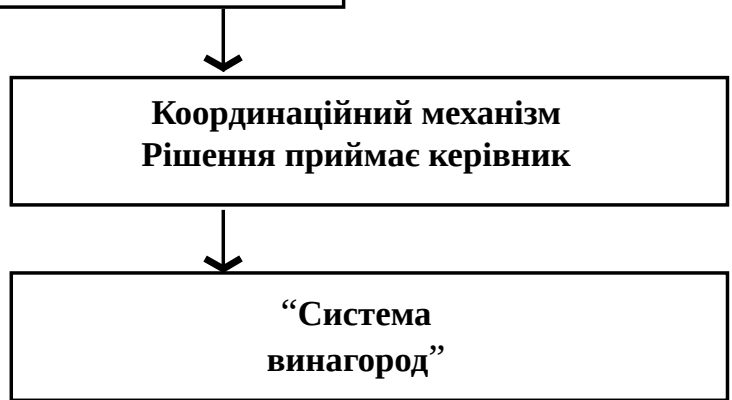

ник розповідає про свою роль та завдання, уважно вислуховує кожну з сторін, їх оцінку конфлікту, а також, які шляхи вони пропонують для виходу 3 конфліктної ситуації та досягнення угоди. Потім посередник пропонує учасникам конфлікту разом з ним прийняти спільне рішення.

Посередник може використовувати прямі методи для розв’язування конфлікту:

а) зустрітися спочатку з однією стороною, а потім вислухати іншу, при цьому головну увагу звернути на факти, а не на емоції. Якщо у посередника 3’явилось рішення, то краще зустрітися з обома сторонами. Після цього посередник висловлює свою думку;

б) дати можливість опонентам висловлювати свої претензії одне одному в присутності інших осіб, які також беруть участь в обговоренні конфлікту. В такому випадку рішення може бути прийнятим від імені групи.

Якщо конфлікт не припиняється - посередниккерівник може вжити санкції до тих, хто його продовжує, особливо в тому випадку, коли зіткнення наносить шкоду загальній справі. Роль посередника має велике значення тоді, коли через конфлікт переговори заходять в “глухий кут”. 
В ролі посередника важливо дотримуватись рекомендацій:

1) створення доброзичливої атмосфери співробітництва (налагодити психологічний контакт);

2) прагнення до якості спілкування (“бути в темі” проблеми);

3) володіння своїми емоціями (“витримка понад усе”);

4) пояснення конфліктуючим сторонам свого ставлення до їх позицій;

5) відкритість до нової інформації (люди, як правило, тягнуться до двосторонньої комунікації, тому у відповідь на вашу цікаву інформацію вони, швидше за все, поділяться своєю) [4].

Висновки. Конфлікти супроводжують нас все життя, але це зовсім не означає, що у всіх конфлік-

\section{Список літератури}

1. Запорожан В. М. Децентралізація в медицині / В. М. Запорожан // Газета “Урядовий кур’єр”. - 2015. № 147 (5521) (13 серпня). - http://ukurier.gov.ua/uk/ articles/decentralizaciya-v-medicini-zasib-chi-panaceya.

2. Гришина Н. В. Психология конфликта / Н. В. Гришина. - 2-е изд. - СПб. : Питер, 2008. - 544 с. - http:// www.law.vsu.ru/structure/criminalistics/books/grishina psy_conf.pdf. тах обов'язково повинна бути сторона, що виграла, i та, що програла. Ми намагаємося розв'язувати конфлікт так, щоб виграли обидві сторони. Про це ми знаємо і до цього прагнемо. До того ж під час вирішення конфліктів можливо краще пізнати лідерів кафедри, з якими довелося спілкуватися в складній ситуації, оволодіти технікою попередження конфліктів та їх розв'язування.

Тоді творчий потенціал, енергія, активність, комунікативні установки, якщо їх генератором і акумулятором є конфлікт, піднімуть культуру спілкування на вищий рівень, сприятимуть вирішенню проблем кафедри і університету в період кардинальних реформ у медицині взагалі, так і реформи медичної освіти відповідно.

3. Корнелиус Х. Выиграть может каждый. Как разрешать конфликты / Х. Корнелиус, Ш. Фэйр ; пер. с англ. М. : Стрингер, 1992. - 216 с. - http://conflict-resolve.org/ conflictresolveintro.pdf.

4. Карнеги Д. Как завоевывать друзей и оказывать влияние на людей / Д. Карнеги ; пер. с англ. - М. : Попурри, 2014. - С. 354. - http://lib.ru/KARNEGY/karnegi1.txt. 